\title{
A novel deletion variant in TRAPPC2 causes spondyloepiphyseal dysplasia tarda in a five-generation Chinese family
}

\author{
Cai Zhang ${ }^{1}$, Caiqi Du', Juan Ye ${ }^{1}$, Feng Ye ${ }^{1}$, Renfa Wang ${ }^{2}$, Xiaoping Luo ${ }^{1}$ and Yan Liang ${ }^{1 *}$ (D)
}

\begin{abstract}
Background: Spondyloepiphyseal dysplasia tarda (SEDT) is a rare X-linked recessive inherited osteochondrodysplasia caused by mutations in the TRAPPC2 gene. It is clinically characterized by disproportionate short stature and early onset of degenerative osteoarthritis. Clinical diagnosis can be challenging due to the lateonset of the disease and lack of systemic metabolic abnomalites. Genetic diagnosis is critical in both early diagnosis and management of the disease. Here we reported a five-generation Chinese SEDT family and described the novel molecular findings.
\end{abstract}

Methods: Detailed family history and clinical data were collected. Genomic DNA was extracted from venous blood samples of family members. The exons of genes known to be associated with skeletal disorders were captured and deep sequenced. Variants were annotated by ANNOVAR and associated with multiple databases. Putative variants were confirmed by Sanger sequencing. The identified variant was classified according to the American College of Medical Genetics (ACMG) criteria.

Results: The proband was a 27-year-old Chinese male who presented with short-trunk short stature and joint pain. His radiographs showed platyspondyly with posterior humping, narrow hip-joint surfaces, and pelvic osteosclerosis. A pedigree analysis of 5 generations with 6 affected males revealed an X-linked recessive mode of inheritance. Affected males were diagnosed as SEDT according to the clinical and radiological features. Next-generation sequencing identified a novel variant of c.216_217del in the exon 4 of TRAPPC2 gene in the proband and other affected males. This variant resulted in the shift of reading frame and early termination of protein translation (p.S73Gfs*15). The mother and maternal female relatives of the proband were heterozygous carriers of the same variant, while no variations were detected in this gene of his father and other unaffected males. Based on the ACMG criteria, the novel c.216_217del variant of the TRAPPC2 gene was the pathogenic variant of this SEDT family.

Conclusion: In this study we identified the novel pathogenic variant of of c.216_217del in the gene of TRAPPC2 in this five-generation Chinese SEDT family. Our findings expand the clinical and molecular spectrum of SEDT and helps the genetic diagnosis of SEDT patients.

Keywords: Spondyloepiphyseal dysplasia tarda, Short stature, TRAPPC2, SEDL

\footnotetext{
* Correspondence: liangyan@tjh.tjmu.edu.cn

'Department of Pediatrics, Tongji Hospital, Tongji Medical College, Huazhong

University of Science and Technology, Wuhan, China

Full list of author information is available at the end of the article
}

\section{$\triangle B M C$}

(c) The Author(s). 2020 Open Access This article is licensed under a Creative Commons Attribution 4.0 International License, which permits use, sharing, adaptation, distribution and reproduction in any medium or format, as long as you give appropriate credit to the original author(s) and the source, provide a link to the Creative Commons licence, and indicate if changes were made. The images or other third party material in this article are included in the article's Creative Commons licence, unless indicated otherwise in a credit line to the material. If material is not included in the article's Creative Commons licence and your intended use is not permitted by statutory regulation or exceeds the permitted use, you will need to obtain permission directly from the copyright holder. To view a copy of this licence, visit http://creativecommons.org/licenses/by/4.0/ The Creative Commons Public Domain Dedication waiver (http://creativecommons.org/publicdomain/zero/1.0/) applies to the data made available in this article, unless otherwise stated in a credit line to the data. 


\section{Background}

Spondyloepiphyseal dysplasia tarda (SEDT, OMIM 313400), is a rare inherited, late-onset osteochondrodysplasia, characterized by disproportionately short stature and premature osteoarthritis [1]. The estimated prevalence in Britain is about 1.7 per 1,000,000 [2]. It is an Xlinked recessive inherited disease whereby only males are affected. The patients have normal growth at birth, but manifestions of this condition become evident after the age of 5-10 years old, with growth retardation, joint pain, and limited mobility [1]. The causative gene of SEDT is TRAPPC2 (previously named SEDL) located on Xp22, which encodes a protein of 140 amino acids, traffic protein particle complex subunit 2 (TRAPPC2), also known as Sedlin [3]. To date, about 50 TRAPPC2 variants responsible for SEDT have been reported (Human Gene Mutation Database, HGMD; http://www.hgmd.cf. ac.uk/ac), and the most common type was deletion mutation. Here, we report a Chinese familial case of SEDT that harbors a novel deletion mutation in TRAPPC2.

\section{Methods}

\section{Genetic analysis}

With the consent of the participants, venous blood samples from 11 members of the family (III4, III5, IV1, IV2, IV3, IV5, IV6, V1, V2, V3, V4 in Fig. 1), and genomic DNA was extracted from each sample. The DNA librariy was prepared by DNA sample prep reagent set (MyGenostics, Beijing). 219 exons known to be associated with skeletal disorders were captured using GenCap WES capture kit (MyGenostics, Beijing) and deep sequenced on the Illumina HiSeq $\mathrm{X}$ ten platform (Illumina, California) [4]. Variants were identified by GATK and annotated with ANNOVAR, and were further associated with multiple databases, such as, 1000 Genomes, ESP6500, dbSNP, EXAC, Inhouse (MyGenostics), HGMD, and predicted by SIFT, PolyPhen-2, MutationTaster, GERP++ [5]. Sanger sequencing was performed to confirm the potentially pathogenic variants. The identified variant was classified according to the American College of Medical Genetics (ACMG) criteria.

\section{Results}

\section{Clinical report}

A 27-year-old Chinese male of short stature (the proband, case V1 in Fig. 1) was presented for genetic counseling due to multiple members of short stature in the family. The pedigree of the Chinese family with short stature is shown in Fig. 1.

The proband (V1) showed stunted growth after the age of 10 years, and experienced mild back pain provoked by exercise after the age of 26 . He was $137.3 \mathrm{~cm}$ (-5.87SDS) tall, with an arm span of $143.5 \mathrm{~cm}$ and an upper to lower body segment ratio of 0.91 . His chest was barrel-shaped, with no notable abnormalities in vertebrae or limbs. The lateral radiograph of the lumbosacral spine showed platyspondyly and dysplasia with posterior humping (Fig. 2a). Flattened femoral heads, narrow hip-joint space and osteosclerosis were observed in the radiograph of the pelvis (Fig. 2b). The radiograph of the knees showed flattened tibial plateaus and irregular surfaces of lateral femoral condyles (Fig. 2c). He was

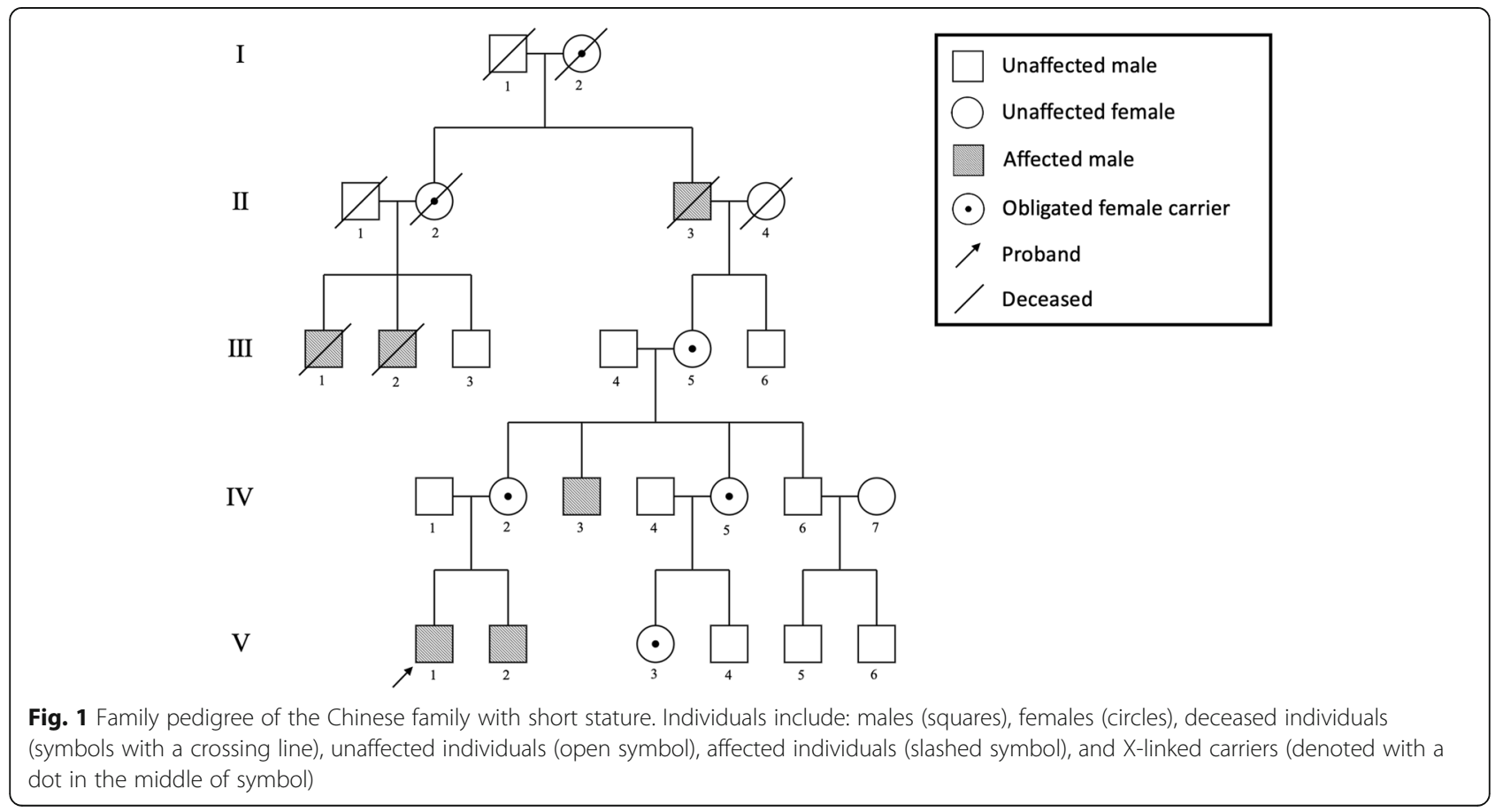



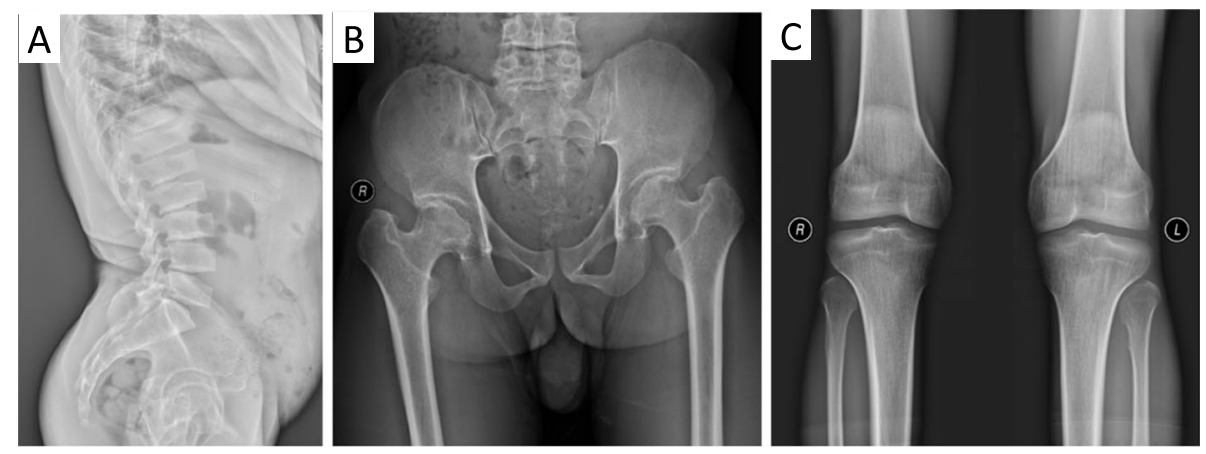

Fig. 2 X-ray radiographs of the proband. a, the radiograph of the lateral lumbosacral spine showed platyspondyly and dysplasia with posterior humping. $\mathbf{b}$, the radiograph of the hips showed flattened femoral heads, narrow hip-joint surfaces, and osteosclerosis of the pelvis. $\mathbf{c}$, the radiograph of the knees displayed flattened tibial plateaus and irregular surface of lateral femur condyles

born to non-consanguineous and normal parents (IV1 and IV2). His father's and mother's height were $170 \mathrm{~cm}$ and $153 \mathrm{~cm}$, respectively. There were 2 other living affected males in the family, identified as the younger bother (V2) and the maternal uncle (IV3) of the proband, who had similar symptoms and manifestations. They all showed stunted growth around the age of 1012 years. Case V2, who was 26 years old and $136 \mathrm{~cm}$ tall, complained of mild back and hip pain provoked by exercise. He had a barrel-shaped chest and no abnomalites of the vertebrae or limbs. Case IV, who was 50 years old and $134 \mathrm{~cm}$ tall, complained of severe back, hip and knee pain, with notable scoliosis and limitation of motion after the fourth decade of his life.

The heights of the affected cases were from 134 to $137 \mathrm{~cm}$, and their chests were all barrel-shaped. X-ray radiography showed typical characteristics of SEDT, including platyspondyly, dysplasia with posterior humping of the vertebral bodies, and osteoarthritic changes in the hip, joints, and the knees. The affected cases were all male with the average height of $136.2 \mathrm{~cm}$, while the heights of the women in this family were normal (the average height was $155.3 \mathrm{~cm}$ ). The proband as well as the maternal uncle and younger bother of the proband were affected. However, the height of the proband's father was normal. These findings indicated an X-linked recessive mode of inheritance. SEDT was diagnosed based on the clinical manifestations, the radiological features, and the inheritance pattern of the family.

\section{Genetic analysis}

Genomic DNA sequencing of the proband revealed a novel hemizygous variant of c.216_217del in the exon 4 of the TRAPPC2 gene (NM_001011658.4) (Fig. 3a), which resulted in the frameshifts and early termination of protein translation (p.S73Gfs"15) (Fig. 3b and Fig. 3c). There was no variant of TRAPPC2 detected in the father of the proband (IV1) (Fig. 3a), while the mother (IV2) was a heterozygous carrier of the c.216 217 del variant (Fig. 3a). This variant appeared to be novel, which is not included in the databased mentioned above, and has not been reported in normal populations. Further analysis of this family showed that the same variant was found in affected case IV3 and $\mathrm{V} 2$, and all maternal female relatives of the proband (III5, IV5, V3) were carriers of the variant. However, no TRAPPC2 variant was detected in phenotypic normal male members (III4, IV6, V4), suggesting the segregation of the variant with the phenotype. Based on the ACMG criteria, the novel c.216_217del variant of the TRAPPC2 gene was the pathogenic variant of this SEDT family.

\section{Discussion}

SEDT is a rare $\mathrm{X}$-linked recessive, progressive osteochondrodysplasia involving vertebral bodies and weightbearing joints [1]. The late-onset of the disease and lack of systemic metabolic abnomalites result in difficulties in diagnosis. Thus genetic testing is critical in both early and prenatal diagnosis.

The causative gene TRAPPC2 is located on $\mathrm{Xp22,}$ which spans a genomic region of approximately $20 \mathrm{~kb}$ and contains six exons. The coding region encompassed by exons $3-6$ is $420 \mathrm{bp}$ in size and encodes 140 -amino acid protein TRAPPC2 [3]. TRAPPC2 binds to other components of traffic protein particle complex (TRAPP) and serves as an adaptor for the formation of the complex, playing a critical role in the traffic of vesicles between the endoplasmic reticulum (ER) and the Golgi complex as well as being involved in the regulation of the ER export of procollagen $[6,7]$. Moreover, it was also reported that TRAPPC2 interacts with multiple transcription factors and perhaps modulates the expression of genes involved in skeletal development [8].

Most of the variants of the TRAPPC2 gene cause premature termination of translation, leading to 


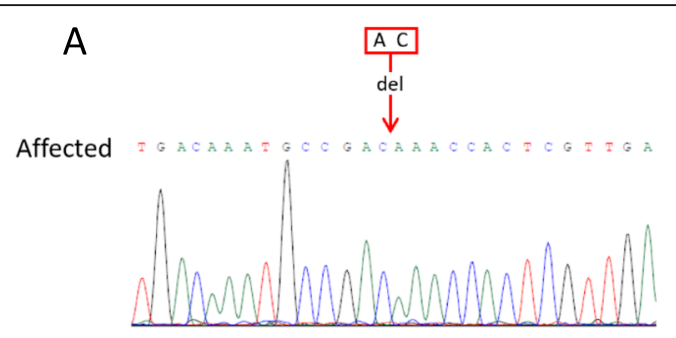

Normal

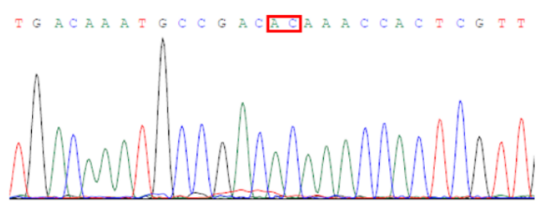

Carrier

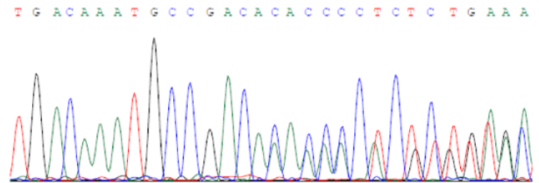

B

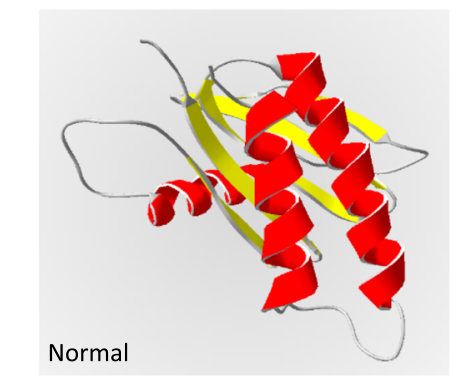

C

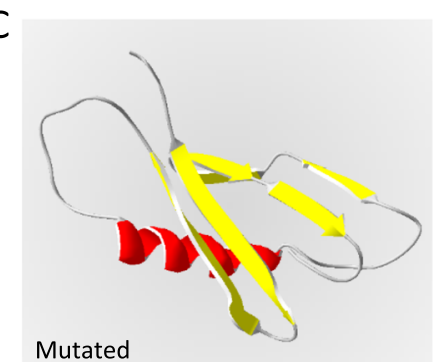

Fig. 3 Sequence analysis of the family and the predicted structure of the mutated protein. a, Sequencing chromatograms of affected members $(\mathrm{V} 1, \mathrm{~V} 2, \mathrm{IV} 3)$, unaffected members (IV1, III4, IV6, V4), and carriers (IV2, III5, IV5, V3) from this family. The red arrow indicates the locus of the c.216_217del variant, and the red box indicates the corresponding normal sequence. $\mathbf{b}$, the predicted secondary structure of the normal TRAPPC2 protein. $\mathbf{c}$, the predicted secondary structure of the mutated TRAPPC2 protein (p. S73Gfs*15)

degradation of partially translated peptides; while some variants result in misfolding of the mutant protein, invoking the protein degradation pathway [9]. All of them deprive the cells of TRAPPC2 function, leading to osteochondrodysplasia. In this study, c.216 $217 \mathrm{del}$ variant of the TRAPPC2 gene resulted in the frameshifts and early termination of protein translation (p.S73Gfs*15), leading to degradation of truncated protein and loss of the TRAPPC2 protein function (Fig. 3b and Fig. 3c).

According to HGMD, there are 54 different pathogenic variants that have been reported so far including the present study, and a majority of them originated from Europe, China, Japan, and Austrialia (Table 1). The variants occur most frequently in exon 4-6 (Fig. 4), which are important regions of protein binding and maintaining the three-dimensional structure of TRAPPC2 protein $[9,37]$. Among these variants, there are 25 deletion mutations (46.3\%), 13 splicing site mutations (24\%), 9 nonsense mutations (16.7\%), 5 missense mutations (9.3\%), and 2 insertion mutations (3.7\%) (Fig. 4). The frequency of the deletion mutations is unusually high, particularly for a gene encoding only 140 amino acids. Homologous recombination and slipped mispairing of five pseudogenes of TRAPPC2 (SEDLP3SEDLP7) on chromosome Yq11.23 may provide a possible explanation of the high frequency of deletion mutations [29]. The novel variant found in this study is a deletion mutation located on exon 4, leading to frameshifts and premature termination of protein translation. There are 3 reported pathogenic variants which are adjacent to it. Among them, two are nonsense mutations that results in truncated protein, while one is a missense mutation that results in misfolding and degradation of the mutated protein [11, 22, 23]. These causative variants suggest that the $5^{\prime}$ region of exon 4 is critical in the structure and function of TRAPPC2.

The correlation of genotype and SEDT phenotype is still unknown. In this study, cases V1 (27 years) and V2 (26 years), complained of only mild joint pain without skeletal abnomalities. But case IV3, who was age 50 years, showed severe joint pain, scoliosis, and limited movement. These intrafamilial phenotypic differences could have possibly resulted from the penetrance of TRAPPC2 mutations and the course of progressive osteoarthritis. Gedeon et al. studied 30 cases of SEDT patients and found no obvious genotype/ phenotype correlation, but a suggestion that variants close to the $5^{\prime}$ end of the TRAPPC 2 gene resulted in severe clincial presentations compared with variants close to the $3^{\prime}$ end. Patients with variants affecting exons 5 and 6 showed a milder condition, with little or no hip pain and neither kyphosis nor scoliosis. Variants in exons 3 and 4 result in kyphosis and scoliosis, severe pain evident earlier in life and a more debilitating set of complications [11]. 
Table 1 Summary of identified pathogenic variants in the TRAPPC2 gene

\begin{tabular}{|c|c|c|c|c|c|c|}
\hline Number & Gene Region & Nucleotide Change & $\begin{array}{l}\text { Mutation } \\
\text { Type }\end{array}$ & $\begin{array}{l}\text { Predicted Amino Acid } \\
\text { Change }\end{array}$ & Origin & $\begin{array}{l}\text { Year of } \\
\text { Report }\end{array}$ \\
\hline 1 & Intron 2 & c. $-19-2 A>C$ & Spice Site & - & Chinese & 2003 [10] \\
\hline 2 & Intron 2 & c. $-19-2 A>G$ & Spice Site & - & French & $2001[11]$ \\
\hline 3 & $\begin{array}{l}\text { Intron } 2 \text { and Exon } \\
3\end{array}$ & deletion 1763 bp across I2E3 boundary & Deletion & - & Japanese & $2001[12]$ \\
\hline 4 & Exon 3 & c.6delT & Deletion & p.S4Afs*4 & Brazilian & 2018 [13] \\
\hline 5 & Exon 3 & c.40delG & Deletion & p.D14lfs*23 & Korean & 2012 [14] \\
\hline 6 & Exon 3 & c.53_54delTT & Deletion & p.F18* & Australian & 1999 [3] \\
\hline 7 & Exon 3 & c.61G $>\mathrm{T}$ & Nonsense & p.E21* & Chinese & 2014 [15] \\
\hline 8 & Exon 3 & Exon3del & Deletion & - & Australian & $2001[11]$ \\
\hline 9 & Intron 3 & $c .93+1 G>A$ & Spice Site & - & Japanese & 2014 [16] \\
\hline 10 & Intron 3 & $c .93+5 G>C$ & Spice Site & - & Chinese & 2013 [17] \\
\hline 11 & Intron 3 & $c .93+5 G>A$ & Spice Site & - & Chinese & 2015 [18] \\
\hline 12 & Intron 3 & $94-2 A>G$ & Spice Site & - & Japanese & 2018 [19] \\
\hline 13 & Exon 4-6 & deletion Exon 4-6 & Deletion & - & European & 2004 [20] \\
\hline 14 & Exon 4 & c.100delC & Deletion & p.H34lfs*3 & European & 2004 [20] \\
\hline 15 & Exon 4 & C.139G > T & Missense & p.D47Y & Danish & $2001[11]$ \\
\hline 16 & Exon 4 & c.157_158delAT & Deletion & p.M53Vfs*34 & Australian & 1999 [3] \\
\hline 17 & Exon 4 & C. $167 C>A$ & Nonsense & p.S56* & Germany & $2003[21]$ \\
\hline 18 & Exon 4 & c. $182 \mathrm{~T}>\mathrm{A}$ & Nonsense & p.L61* & Mexican & $2001[11]$ \\
\hline 19 & Exon 4 & c.183_184delGA & Deletion & p.K62Nfs*25 & European & 2004 [20] \\
\hline 20 & Exon 4 & c.191_192delTG & Deletion & p.V64Gfs*23 & Australian & 1999 [3] \\
\hline 21 & Exon 4 & c. $209 \mathrm{G}>\mathrm{A}$ & Nonsense & p.W70* & Chinese & 2008 [22] \\
\hline 22 & Exon 4 & $c .210 G>A$ & Nonsense & p.W70* & European & $2001[23]$ \\
\hline 23 & Exon 4 & c.216_217del & Deletion & p.S73Gfs*15 & Chinese & $\begin{array}{l}\text { Present } \\
\text { Study }\end{array}$ \\
\hline 24 & Exon 4 & c. $218 \mathrm{C}>\mathrm{T}$ & Missense & p.S73L & Norwegian & $2001[11]$ \\
\hline 25 & Intron 4 & $c .238+1 A>G$ & Spice Site & - & Chinese & 2009 [24] \\
\hline 26 & Intron 4 & $c .238+4 T>C$ & Spice Site & - & Italian & $2003[25]$ \\
\hline 27 & Intron 4 & c.239-11_239-9delAAT & Spice Site & - & Turkish & $2014[26]$ \\
\hline 28 & Intron 4 & c.239-11_239-4delAATTATTा & Spice Site & - & German & $2001[11]$ \\
\hline 29 & Intron 4 & c.239-10_239-7delATTA & Spice Site & - & North American & $2001[11]$ \\
\hline 30 & Exon5 & c. $239 A>G$ & Missense & p.H80R & Chinese & $2008[27]$ \\
\hline 31 & Exon 5 & c.241_242delAT & Deletion & p.M81Efs*6 & French & $2001[11]$ \\
\hline 32 & Exon 5 & c. $248 \mathrm{~T}>\mathrm{C}$ & Missense & p.F83S & British & $2001[28]$ \\
\hline 33 & Exon 5 & c.262_266delGACAT & Deletion & p.D88Kfs*11 & Canadian & $2001[11]$ \\
\hline 34 & Exon 5 & $c .271 \mathrm{C}>\mathrm{T}$ & Nonsense & p.Q91* & - & 2000 [29] \\
\hline 35 & Exon 5 & c.271_275delCAAGA & Deletion & p.Q91Rfs*8 & North American & $2000[30]$ \\
\hline 36 & Exon 5 & c.272_273delAA & Deletion & p.Q91Rfs*9 & Finnish & 2001 [11] \\
\hline 37 & Exon 5 & c.293delT & Deletion & p.F98Sfs*10 & Chinese & $2003[31]$ \\
\hline 38 & Exon 5 & c.320dupT & Insertion & p.F109Vfs*7 & $\begin{array}{l}\text { Native } \\
\text { Australian }\end{array}$ & 2001 [11] \\
\hline 39 & Intron 5 & c.325-10_325-4delTCTTTCCinsAA & Spice Site & - & French & $2001[11]$ \\
\hline 40 & Intron 5 & c. $325-2 A>C$ & Spice Site & - & Australian & $2001[11]$ \\
\hline 41 & $\begin{array}{l}\text { Intron } 5 \text { and Exon } \\
6\end{array}$ & deletion $1330 \mathrm{bp}$ across I5E6 & Deletion & - & Australian & 2001 [11] \\
\hline
\end{tabular}


Table 1 Summary of identified pathogenic variants in the TRAPPC2 gene (Continued)

\begin{tabular}{|c|c|c|c|c|c|c|}
\hline Number & Gene Region & Nucleotide Change & $\begin{array}{l}\text { Mutation } \\
\text { Type }\end{array}$ & $\begin{array}{l}\text { Predicted Amino Acid } \\
\text { Change }\end{array}$ & Origin & $\begin{array}{l}\text { Year of } \\
\text { Report }\end{array}$ \\
\hline 42 & $\begin{array}{l}\text { Intron } 5 \text { and Exon } \\
6\end{array}$ & deletion 1335 bp across I5E6 boundary & Deletion & - & Belgian & $2003[25]$ \\
\hline 43 & $\begin{array}{l}\text { Intron } 5 \text { and Exon } \\
6\end{array}$ & $\begin{array}{l}\text { deletion } 1371-1445 \text { bp across I5E6 } \\
\text { boundary }\end{array}$ & Deletion & - & European & 2001 [23] \\
\hline 44 & $\begin{array}{l}\text { Intron } 5 \text { and Exon } \\
6\end{array}$ & deletion 750 bp across I5E6 boundary & Deletion & - & European & 2001 [23] \\
\hline 45 & $\begin{array}{l}\text { Intron } 5 \text { and Exon } \\
6\end{array}$ & c.325-2_335delAGTTTTCAATGAA & Deletion & p.F109Sfs*3 & Chinese & 2004 [32] \\
\hline 46 & Exon 6 & c.328delT & Deletion & p.S110Qfs*1 & European & 2004 [20] \\
\hline 47 & Exon 6 & C. 329 C > A & Nonsense & p.S110* & Chinese & 2002 [33] \\
\hline 48 & Exon 6 & c.333_336delGAAT & Deletion & p.M111lfs*29 & Slovakian & $2003[25]$ \\
\hline 49 & Exon 6 & c.345_346delTG & Deletion & p.Y115* & European & 2004 [20] \\
\hline 50 & Exon 6 & c. $364 C>T$ & Nonsense & p.R122* & European & 2001 [23] \\
\hline 51 & Exon 6 & c.370dupA & Insertion & p.S124Kfs*3 & Chinese & 2009 [34] \\
\hline 52 & Exon 6 & c.387delA & Deletion & p.V130Ffs*9 & $\begin{array}{l}\text { Jewish } \\
\text { Ashkenazi }\end{array}$ & 2004 [35] \\
\hline 53 & Exon 6 & c. $389 \mathrm{~T}>\mathrm{A}$ & Missense & p.V130D & Japanese & 2001 [11] \\
\hline 54 & Exon 6 & c.391C $>\mathrm{T}$ & Nonsense & p.Q131* & Japanese & 2002 [36] \\
\hline
\end{tabular}

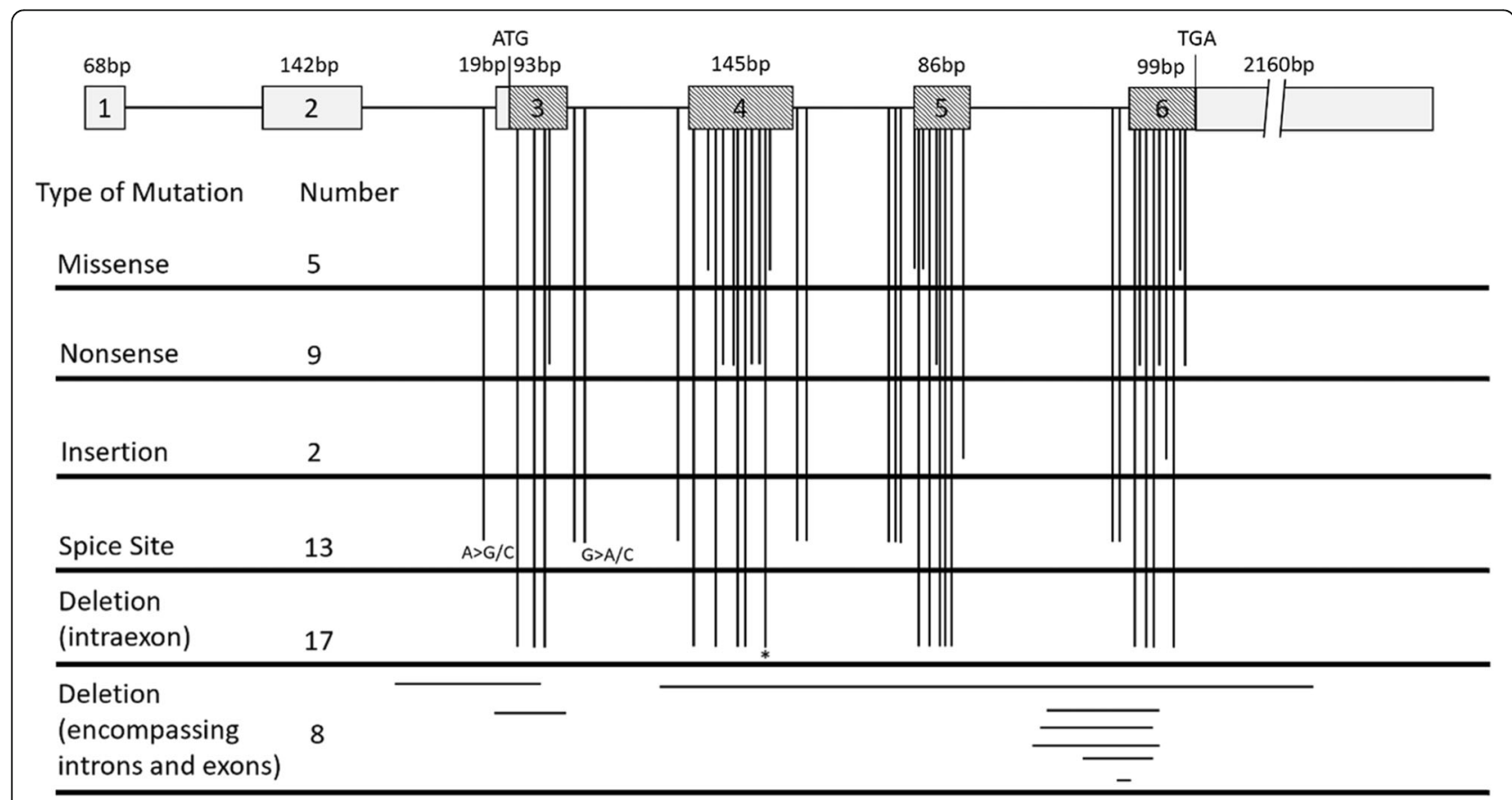

Fig. 4 The summary of identified variants in the TRAPPC2 gene illustrated by a schematic diagram. The human TRAPPC2 gene consists of six exons that span approximately $20 \mathrm{~kb}$ of genomic DNA. The $420 \mathrm{bp}$ coding region (hatched boxes) is organized into four exons (exon 3 to exon 6). Non-coding exons (open boxes) consist of exons 1 and 2, the $5^{\prime}$ portion of exon 3, and the 3' portion of exon 6. The translation Start (ATG) and Stop (TGA) codons in exon 3 and 6, respectively, are indicated. Introns are indicated by a line (not to scale). The locations of the 54 variants are indicated, including the variant identified in this study (denoted by the asterisk) 


\section{Conclusions}

In conclusion, we report a novel pathogenic variant (c.216_217del) of the TRAPPC2 gene in this SEDT family. Our findings enable carrier detection, genetic counseling, and asymptomatic/prenatal diagnosis. Identification of the novel disease-causing mutaiton will assist in further elucidation of the role of the TRAPPC2 protein in bone growth.

\section{Abbreviations}

SEDT: Spondyloepiphyseal dysplasia tarda; TRAPPC2: Traffic protein particle complex subunit 2; HGMD: Human Gene Mutation Database

\section{Acknowledgments}

We are thankful to the participating family. We also thank Ann Minh Vuong for English revision.

\section{Authors' contributions}

$\mathrm{CZ}, \mathrm{XL}$, and $\mathrm{YL}$ designed and organized the study. $\mathrm{CZ}, \mathrm{FY}$, and RW have enrolled the patients and contributed to the interpretation of the clinical data and sequencing results. CD and JY carried out the molecular genetic studies. $C Z$ and $Y L$ wrote the manuscript that was edited by all other authors. All authors read and approved the final manuscript.

\section{Funding}

No funding was obtained for this study.

\section{Availability of data and materials}

The data generated during the current study are available on online public repository ClinVar (https://submit.ncbi.nlm.nih.gov/clinvar/). An accession number (VCV000694600.1) for the novel variant identified in this study has also been allocated (https://www.ncbi.nlm.nih.gov/clinvar/variation/ 694600/). The raw datasets generated and analysed during the current study are not publicly available in order to protect participant confidentiality.

\section{Ethics approval and consent to participate}

This study was approved by the Ethics Committee of Tongji Hospital, Tongji Medical College of Huazhong University of Science and Techonlogy (TJIRB20180703). Written informed consent to participate was obtained from each participant.

\section{Consent for publication}

Written informed consent to publish was obtained from each participant.

\section{Competing interests}

The authors declare that they have no conflict of interest.

\section{Author details}

'Department of Pediatrics, Tongji Hospital, Tongji Medical College, Huazhong University of Science and Technology, Wuhan, China. ${ }^{2}$ Department of Radiology, Tongji Hospital, Tongji Medical College, Huazhong University of Science and Technology, Wuhan, China.

Received: 9 December 2019 Accepted: 19 May 2020

Published online: 29 May 2020

\section{References}

1. Savarirayan R, Thompson E, Gecz J. Spondyloepiphyseal dysplasia tarda (SEDL, MIM \#313400). Eur J Hum Genet. 2003;11(9):639-42.

2. Wynne-Davies R, Gormley J. The prevalence of skeletal dysplasias. An estimate of their minimum frequency and the number of patients requiring orthopaedic care. The Journal of bone and joint surgery British volume. 1985;67(1):133-7.

3. Gedeon AK, Colley A, Jamieson R, Thompson EM, Rogers J, Sillence D, Tiller GE, Mulley JC, Gecz J. Identification of the gene (SEDL) causing X-linked spondyloepiphyseal dysplasia tarda. Nat Genet. 1999;22(4):400-4.

4. Wu J, Matthaei H, Maitra A, Dal Molin M, Wood LD, Eshleman JR, Goggins M, Canto MI, Schulick RD, Edil BH et al: Recurrent GNAS mutations define an unexpected pathway for pancreatic cyst development. Science translational medicine 2011, 3(92):92ra66.

5. Wang K, Li M, Hakonarson H. ANNOVAR: functional annotation of genetic variants from high-throughput sequencing data. Nucleic Acids Res. 2010; 38(16):e164.

6. Venditti R, Scanu T, Santoro M, Di Tullio G, Spaar A, Gaibisso R, Beznoussenko GV, Mironov AA, Mironov A Jr, Zelante L, et al. Sedlin controls the ER export of procollagen by regulating the Sar1 cycle. Science. 2012; 337(6102):1668-72.

7. Zong M, Wu XG, Chan CW, Choi MY, Chan HC, Tanner JA, Yu S. The adaptor function of TRAPPC2 in mammalian TRAPPs explains TRAPPC2-associated SEDT and TRAPPC9-associated congenital intellectual disability. PLoS One. 2011;6(8):e23350.

8. Jeyabalan J, Nesbit MA, Galvanovskis J, Callaghan R, Rorsman P, Thakker RV. SEDLIN forms homodimers: characterisation of SEDLIN mutations and their interactions with transcription factors MBP1, PITX1 and SF1. PLoS One. 2010; 5(5):e10646.

9. Choi MY, Chan CC, Chan D, Luk KD, Cheah KS, Tanner JA. Biochemical consequences of sedlin mutations that cause spondyloepiphyseal dysplasia tarda. Biochem J. 2009;423(2):233-42.

10. Gao C, Luo Q, Wang HL, Gao XQ, Fan QT, Wang H, Sheng GY, Zhou JH, Gao TZ. Identification of a novel mutation IVS2-2A->C of SEDL gene in a Chinese family with X-linked spondyloepiphyseal dysplasia tarda. Zhonghua Yi Xue Yi Chuan Xue Za Zhi. 2003;20(1):15-8.

11. Gedeon AK, Tiller GE, Le Merrer M, Heuertz S, Tranebjaerg L, Chitayat D, Robertson S, Glass IA, Savarirayan R, Cole WG, et al. The molecular basis of X-linked spondyloepiphyseal dysplasia tarda. Am J Hum Genet. 2001;68(6): 1386-97.

12. Matsui Y, Yasui N, Ozono K, Yamagata M, Kawabata H, Yoshikawa H. Loss of the SEDL gene product (Sedlin) causes $X$-linked spondyloepiphyseal dysplasia tarda: identification of a molecular defect in a Japanese family. Am I Med Genet. 2001;99(4):328-30.

13. Gomes MES, Kanazawa TY, Riba FR, Pereira NG, Zuma MCC, Rabelo NC, Sanseverino MT, Horovitz DDG, Llerena JC Jr, Cavalcanti DP, et al. Novel and recurrent mutations in the FGFR3 gene and Double Heterozygosity cases in a cohort of Brazilian patients with skeletal dysplasia. Molecular Syndromol. 2018;9(2):92-9.

14. Kim HJ, Lee BH, Kim YM, Kim GH, Kim OH, Yoo HW. A case with Spondyloepiphyseal dysplasia Tarda with TRAPPC2 mutation. J Genet Med. 2012;9:31-4.

15. Xia XY, Yu J, Li WW, Li N, Wu QY, Zhou X, Cui YX, Li XJ. A novel nonsense mutation in the sedlin gene (SEDL) causes severe spondyloepiphyseal dysplasia tarda in a five-generation Chinese pedigree. Genet Mol Res. 2014; 13(2):3362-70

16. Adachi H, Takahashi I, Takahashi T. Novel TRAPPC2 mutation in a boy with X-linked spondylo-epiphyseal dysplasia tarda. Pediatr Int. 2014;56(6):925-8.

17. Wang $\mathrm{H}, \mathrm{Wu} W, \mathrm{Xu} Z$, Xie J. A novel splicing mutation in the SEDL gene causes spondyloepiphyseal dysplasia tarda in a large Chinese pedigree. Clin Chim Acta. 2013:425:30-3.

18. Wu X, Deng K, Wang C, Li G, Lin J, Wang R, Wu H, Huang S. Mutation analysis of the TRAPPC2 gene in a Chinese family with $X$-linked spondyloepiphyseal dysplasia tarda. Zhonghua Yi Xue Yi Chuan Xue Za Zhi. 2015:32(4):476-80.

19. Fukuma M, Takagi M, Shimazu T, Imamura H, Yagi H, Nishimura G, Hasegawa T. A familial case of spondyloepiphyseal dysplasia tarda caused by a novel splice site mutation in TRAPPC2. Clin Pediatr Endocrinol. 2018;27(3):193-6.

20. Fiedler J, Le Merrer M, Mortier G, Heuertz S, Faivre L, Brenner RE. X-linked spondyloepiphyseal dysplasia tarda: novel and recurrent mutations in 13 European families. Hum Mutat. 2004:24(1):103.

21. Fiedler J, Bergmann C, Brenner RE. X-linked spondyloepiphyseal dysplasia tarda: molecular cause of a heritable disorder associated with early degenerative joint disease. Acta Orthop Scand. 2003;74(6):737-41.

22. Zhu HY, Li J, Zhu RF, Wu X, Duan HL, Yang Y, Zhang Y, Hu Y. Mutational analysis in a family with $X$-linked spondyloepiphyseal dysplasia tarda. Zhonghua Yi Xue Yi Chuan Xue Za Zhi. 2008;25(4):421-3.

23. Christie PT, Curley A, Nesbit MA, Chapman C, Genet S, Harper PS, Keeling SL, Wilkie AO, Winter RM, Thakker RV. Mutational analysis in X-linked spondyloepiphyseal dysplasia tarda. J Clin Endocrinol Metab. 2001;86(7): 3233-6.

24. Xiong F, Gao J, Li J, Liu Y, Feng G, Fang W, Chang H, Xie J, Zheng H, Li T, et al. Noncanonical and canonical splice sites: a novel mutation at the rare 
noncanonical splice-donor cut site (IVS4+1A>G) of SEDL causes variable splicing isoforms in X-linked spondyloepiphyseal dysplasia tarda. Eur J Hum Genet. 2009;17(4):510-6.

25. Shaw MA, Brunetti-Pierri N, Kadasi L, Kovacova V, Van Maldergem L, De Brasi D, Salerno M, Gecz J. Identification of three novel SEDL mutations, including mutation in the rare, non-canonical splice site of exon 4. Clin Genet. 2003: 64(3):235-42.

26. Davis EE, Savage $J H$, Willer JR, Jiang $Y H$, Angrist $M$, Androutsopoulos $A$, Katsanis $\mathrm{N}$. Whole exome sequencing and functional studies identify an intronic mutation in TRAPPC2 that causes SEDT. Clin Genet. 2014;85(4): 359-64.

27. Lin Y, Rao SQ, Yang Y. A novel mutation in the SEDL gene leading to $X$ linked spondyloepiphyseal dysplasia tarda in a large Chinese pedigree. Zhonghua Yi Xue Yi Chuan Xue Za Zhi. 2008;25(2):150-3.

28. Grunebaum E, Arpaia E, Mackenzie JJ, Fitzpatrick J, Ray PN, Roifman CM. A missense mutation in the SEDL gene results in delayed onset of $X$ linked spondyloepiphyseal dysplasia in a large pedigree. J Med Genet. 2001;38(6):409-11.

29. Gecz J, Hillman MA, Gedeon AK, Cox TC, Baker E, Mulley JC. Gene structure and expression study of the SEDL gene for spondyloepiphyseal dysplasia tarda. Genomics. 2000;69(2):242-51.

30. Mumm S, Christie PT, Finnegan P, Jones J, Dixon PH, Pannett AA, Harding B, Gottesman GS, Thakker RV, Whyte MP. A five-base pair deletion in the sedlin gene causes spondyloepiphyseal dysplasia tarda in a six-generation Arkansas kindred. J Clin Endocrinol Metab. 2000;85(9):3343-7.

31. Xiao C, Zhang S, Wang J, Qiu W, Chi L, Li Y, Su Z. A single nucleotide deletion of 293delT in SEDL gene causing spondyloepiphyseal dysplasia tarda in a four-generation Chinese family. Mutat Res. 2003;525(1-2):61-5.

32. Lu JF, Ma HW, Jiang J, Niu GH, Liu XM. Identification of a novel mutation of the SEDL gene in X-linked spondyloepiphyseal dysplasia tarda. Zhonghua Yi Xue Yi Chuan Xue Za Zhi. 2004;21(4):309-11.

33. Shi YR, Lee CC, Hsu YA, Wang CH, Tsai FJ. A novel nonsense mutation of the sedlin gene in a family with spondyloepiphyseal dysplasia tarda. Hum Hered. 2002;54(1):54-6.

34. Xia XY, Cui YX, Zhou YC, Zhou X, Shi YC, Wei L, Li XJ, Huang YF, Huang TT. A novel insertion mutation in the SEDL gene results in $X$-linked spondyloepiphyseal dysplasia tarda in a large Chinese pedigree. Clin Chim Acta. 2009;410(1-2):39-42.

35. Bar-Yosef U, Ohana E, Hershkovitz E, Perlmuter S, Ofir R, Birk OS. X-linked spondyloepiphyseal dysplasia tarda: a novel SEDL mutation in a Jewish Ashkenazi family and clinical intervention considerations. Am J Med Genet A. 2004;125A(1):45-8.

36. Takahashi T, Takahashi I, Tsuchida S, Oyama K, Komatsu M, Saito H, Takada G. An SEDL gene mutation in a Japanese kindred of X-linked spondyloepiphyseal dysplasia tarda. Clin Genet. 2002;61(4):319-20.

37. Jang SB, Kim YG, Cho YS, Suh PG, Kim KH, Oh BH. Crystal structure of SEDL and its implications for a genetic disease spondyloepiphyseal dysplasia tarda. J Biol Chem. 2002;277(51):49863-9.

\section{Publisher's Note}

Springer Nature remains neutral with regard to jurisdictional claims in published maps and institutional affiliations.

Ready to submit your research? Choose BMC and benefit from:

- fast, convenient online submission

- thorough peer review by experienced researchers in your field

- rapid publication on acceptance

- support for research data, including large and complex data types

- gold Open Access which fosters wider collaboration and increased citations

- maximum visibility for your research: over $100 \mathrm{M}$ website views per year

At BMC, research is always in progress.

Learn more biomedcentral.com/submissions 